\author{
Nurul Leyly Rachmawati \\ UIN Sunan Kalijaga Yogyakarta
}

nurulleyly@gmail.com

\section{Penyimpangan Prinsip Kerja Sama dan Prinsip Kesantunan dalam Cerita Pendek Jannah al-Athfâl}

DOI: $10.18196 / \mathrm{mht} .2113$

\begin{abstract}
This study aimed at describing the deviations of the cooperative principle and the politeness principle in the short story of Jannah al-Athfall written by Naguib Mahfouz. The type of this research was a descriptive study. The research analysis result showed that there were some deviations from both of the principles in the short story of Jannah al-Athfall by Naguib Mahfouz. There were 10 utterances included in the deviation of cooperative principle which consisted of 4 maxims, namely: 1 quantity maxim, 1 quality maxim, 4 relevance maxims, and 4 implementation maxims. Whereas, the politeness principle deviation was found in 14 utterances which consisted of 3 maxims, namely: 2 wisdom maxims, 4 mercy maxims, and 8 matching maxims. Meanwhile, the deviations of modesty maxim, acceptance maxim, and sympathy maxim were not found in the data.
\end{abstract}

Keywords: cooperative principle, politeness principle, short story, Jannah al-Athfâl

\title{
ABSTRAK
}

Penelitian ini bertujuan mendeskripsikan bentuk penyimpangan prinsip kerja sama dan prinsip kesantunan pada cerita pendek Jannah al-Athfâl karya Naguib Mahfouz. Jenis penelitian ini merupakan penelitian deskriptif. Hasil analisis penelitian menunjukkan adanya penyimpangan prinsip kerja sama dan prinsip kesantunan pada cerita pendek Jannah al-Athfâl karya Naguib Mahfouz. Penyimpangan prinsip kerja sama sebanyak 10 tuturan, terdiri dari 4 maksim yaitu 1 maksim kuantitas, 1 maksim kualitas, 4 maksim relevansi, dan 4 maksim pelaksanaan. Sedangkan penyimpangan prinsip kesantunan ditemukan sebanyak 14 tuturan, yang terdiri dari 3 maksim yaitu 2 maksim kebijaksanaan, 4 maksim kemurahan, dan 8 maksim kecocokan. Adapun maksim kerendahan hati, maksim penerimaan, dan maksim kesimpatian tidak ditemukan penyimpangan-penyimpangan pada data.

Kata kunci: prinsip kerja sama, prinsip kesantunan, cerita pendek, Jannah al-Athfâl

\section{PENDAHULUAN}

Manusia, sebagai makhluk sosial, membutuhkan saling berinteraksi satu sama lain dalam kegiatan bersosial. Kegiatan berinteraksi akan berjalan dengan baik dan membutuhkan proses berkomunikasi yang berlaku. Proses tersebut dapat ditemukan dalam lingkungan yang paling kecil, yaitu keluarga hingga lingkungan yang lebih besar, yaitu masyarakat. Salah satu alat untuk menyampaikan perasaan dan pikirannya adalah bahasa. Tidak ada masyarakat tanpa bahasa dan tidak pula bahasa tanpa masyarakat (Soeparno 2002, 5).

Dalam sebuah pertuturan harus adanya sebuah kerja sama antar penutur, jika ingin proses komunikasi berjalan dengan baik dan lancar. Oleh karena itu, sebuah prinsip kerja sama harus ada dalam sebuah pertuturan. Setiap penutur dan lawan 
tutur bertanggung jawab terhadap tindakan dan penyimpangan kaidah yang mengatur tindakan, penggunaan bahasa, dan interpretasi-interpretasinya terhadap tindakan dan ucapan lawan tuturnya. Berkomunikasi tidak selamanya berkaitan dengan masalah yang bersifat tekstual, tetapi juga interpersonal sehingga perlu disikapi sebagai fenomena pragmatik.

\section{LANDASAN TEORI}

Pragmatik merupakan cabang ilmu linguistik yang sedang berkembang pada masa sekarang ini. Banyak ahli bahasa mengemukakan tentang definisi pragmatik. Definisi pragmatik yang dibuat oleh Levinson $(1983,17)$ adalah "pragmatics is study of the relation between language and context that are basic to an account of language understanding" (pragmatik adalah ilmu tentang hubungan antara bahasa dan konteks yang didasarkan pada perhitungan pemahaman bahasa. Definisi ini menegaskan bahwa kontkes adalah dasar dari pemahaman bahasa).

Dalam kehidupan sehari-hari tidak jarang ditemukan penyimpanganpenyimpangan dalam kaidah bertutur yang tertuang, baik dalam prinsip kerja sama maupun prinsip kesantunan. Prinsip tersebut tidak hanya kita temukan melalui komunikasi lisan, tetapi juga melalui media komunikasi tulisan. Salah satunya adalah dalam karya sastra, baik itu novel, cerita pendek, wacana humor, pidato, dan lain sebagainya.

Strategi-strategi yang digunakan manusia dalam bertutur dirumuskan oleh Grice (1975) dalam prinsip-prinsip kerja sama dan prinsip kesantunan oleh Leech (1983). Prinsip kerja sama mengacu pada kaidah bertutur yang berisikan sejumlah tuntunan bagaimana seharusnya seseorang bertutur. Terkadang dalam berkomunikasi, secara verbal maupun nonverbal, sering terjadi pelanggaran prinsipprinsip kerja sama dan prinsip kesantunan, baik disengaja maupun tidak disengaja. Seperti yang dikatakan oleh Leech (dalam Rahardi 2005, 41), "Prinsip kerja sama Grice tidak sepenuhnya dipatuhi dan harus ditepati. Hal tersebut disebabkan oleh dua hal. Pertama, prinsip kerja sama Grice tidak dapat menjelaskan alasan penutur kadangkadang tidak menyatakan langsung maksud yang ingin dituturkannya. Kedua, Prinsip kerja sama Grice tidak dapat menjelaskan hubungan antara rasa dan daya apabila tuturan nondeklaratif muncul dalam komunikasi yang sebenarnya." Selain itu, prinsip kesantunan Leech adalah prinsip yang dibahas di dalam penelitian ini dikarenakan prinsip Leech merupakan prinsip yang secara lengkap dan dapat mewakili beberapa teori yang lainnya.

Oleh karena itu, antara penutur dan lawan tutur harus kooperatif agar komunikasi berjalan lancar dan ada prinsip kerja sama yang harus dilakukan penutur dan lawan tutur. Selain prinsip kerja sama, prinsip kesantunan juga harus diperhatikan dalam sebuah percakapan agar dalam sebuah percakapan tidak ada yang saling dirugikan (Setyowati 2014, 1).

Dalam penelitian ini, peneliti membahas tentang penyimpangan-penyimpangan prinsip kerja sama dan prinsip kesantunan dalam cerita pendek Jannah al-Athfâlkarya Naguib Mahfouz. Cerita tersebut sangat menarik untuk diteliti karena terdapat banyak hikmah yang dapat dipetik bagi anak-anak dan orang tua, di antaranya adalah 
pembelajaran agama dari orangtua kepada anak (Mega, 2010: 1). Selain itu, sebagai karya sastra yang menarik, peneliti menemukan fenomena-fenomena kebahasaan dalam cerita pendek tersebut, salah satunya adalah tuturan yang terdapat dalam

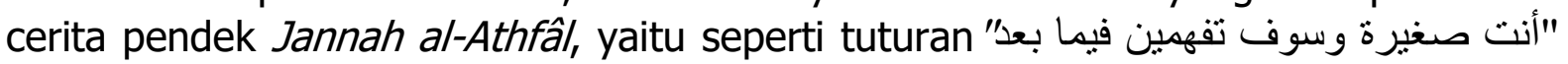
(kamu masih kecil dan kamu akan memahaminya nanti). Tuturan tersebut dituturkan oleh lawan tutur yaitu ayah dari si anak kecil yang sedang berbicara santai dengan ayah dan ibunya terkait teman sekolahnya yang berbeda agama, yaitu Nadia. Lalu di balas dengan tuturan oleh penutur pertama, "أنا كبيرة يا بابا" (Aku sudah besar, wahai Ayah). Tuturan dari penutur ini melanggar prinsip kerja sama, yaitu maksim kualitas. Dalam maksim ini seharusnya penutur memberikan kontribusi yang sesuai dengan kenyataan dan bukti-bukti yang valid. Namun, dapat kita lihat dalam tuturan tersebut penutur memberikan tuturan yang sebaliknya.

Dari penjelasan tersebut, peneliti merasa tertarik untuk menelitinya dalam bidang kajian pragmatik. Peneliti memutuskan untuk meneliti penyimpanganpenyimpangan prinsip kerja sama dan prinsip kesantunan dalam cerita pendek Jannah al-Athfâl karya Naguib Mahfouz tersebut. Oleh karena itu, peneliti merumuskan judul "Penyimpangan Prinsip Kerja Sama dan Prinsip Kesopanan dalam Cerita Pendek Jannah al-Athfâl."

\section{METODE PENELITIAN}

Penelitian tentang prinsip kerja sama dan prinsip kesantunan dalam cerita pendek Jannah al-Athfâl ini merupakan penelitian deskriptif. Metode penelitian deskriptif adalah metode yang bertujuan membuat deskripsi, yaitu membuat gambaran dan lukisan secara sistematis, faktual, dan akurat mengenai data, sifat-sifat serta hubungan fenomena-fenomena yang diteliti (Djajasudarma 2010, 9). Data yang sudah dikumpulkan selanjutnya dianalisis tuturan demi tuturan.

\section{TEKNIK PENGUMPULAN DATA}

Dalam penelitian ini teknik yang digunakan adalah teknik simak bebas libat cakap dan teknik catat. Dalam teknik simak bebas libat cakap, peneliti hanya berperan sebagai pengamat penggunaan bahasa oleh para informannya. Peneliti tidak terlibat langsung dalam peristiwa pertuturan yang bahasanya sedang diteliti (Mahsun 2006, 91). Sedangkan teknik catat yaitu dilakukan pencatatan pada kartu data yang kemudian segera dilanjutkan dengan klasifikasi. Pengklasifikasian meliputi maksimmaksim prinsip kerja sama dan prinsip kesantunan, mengategorikan maksim-maksim prinsip kerja sama dan prinsip kesantunan dalam suatu daftar, penyimpangan maksim dalam prinsip kerja sama dan prinsip kesantunan, dan menyimpulkannya.

\section{HASIL PENELITIAN DAN PEMBAHASAN}

Berdasarkan penelitian yang telah dilakukan, ditemukan bentuk penataan dan penyimpangan prinsip kerja sama dan prinsip kesantunan dalam cerita pendek Jannah al-Athfâl. Penataan prinsip kerja sama tersebut berupa penataan maksim kuantitas yang menginginkan pemberian kontribusi yang berlebihan, maksim kualitas yang menginginkan pemberian kontribusi yang sesuai dengan fakta, maksim relevansi yang 
menginginkan kontribusi yang sesuai dengan masalah yang sedang dituturkan, dan maksim cara yang menghendaki kontibusi yang jelas.

Penyimpangan prinsip kesantunan terdiri enam maksim, yaitu penyimpangan; 1) maksim kebijaksanaan, 2) maksim kemurahan, 3) maksim penerimaan, 4) maksim kerendahan hati, 5) maksim kecocokan, dan 6) maksim kesimpatian.

Hasil penelitian menerangkan bahwa dalam cerita pendek Jannah al-Athfâl karya Naguib Mahfouz, peneliti menemukan dua jenis bentuk penyimpangan, yaitu penyimpangan prinsip kerja sama dan penyimpangan prinsip kesantunan.

\section{Penyimpangan Prinsip Kerja Sama dalam Cerita Pendek Jannah al-Athfâl Karya Naguib Mahfouz.}

a. Penyimpangan Maksim Kuantitas

في الفصل، في الفسحة، وساعة الأكل (Di kelas, saat istirahat, dan saat makan siang)

Pada tuturan di atas, penutur atau anak perempuan ini melanggar maksim kuantitas yaitu dengan memberikan kontribusi informasi yang berlebihan. Tuturan ini menunjukkan penjelasan yang terlalu berlebihan, sehingga dapat melanggar prinsip ini.

b. Penyimpangan Maksim Kualitas

مثلك يا بابا؟ (Sepertimu, wahai Ayah?)

c. Penyimpangan Maksim Relevansi

- هل لأن باباها يلبس نظّارة: (Apa karena bapaknya berkaca mata?)

Pada tuturan di atas, informasi yang diberikan oleh penutur, yaitu anak perempuan ini tidak relevan dengan masalah yang ada dan tuturan sebelumnya, yaitu yang dituturkan oleh ayahnya, "Bapak dan ibunya Kristen. Sebab itu, ia juga Kristen."

- الا تنتظرين حتى تكبري؟ (Apa tidak tunggu saja sampai kamu besar nanti?)

Menurut peneliti, tuturan di atas yang dituturkan oleh ayahnya kepada anak perempuan tersebut tidak ada hubungannya dengan masalah yang ada.

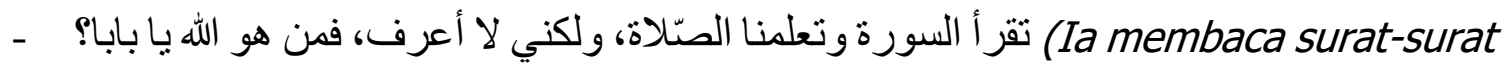
Al-Quran dan mengajari kami sembahyang, tapi saya tidak tahu siapa Allah itu, wahai Ayah?)

Tuturan yang dituturkan oleh anak perempuan di atas menyimpang pelanggaran maksim relevansi karena tidak memiliki relevansi dengan tuturan dari lawan tutur, yaitu dengan tuturan, "Apa kata Bu Guru di sekolah?" 
Tuturan pertanyaan ini mengandung implikasi untuk mengalihkan dari pertanyaan anak perempuan tersebut.

- منألك يا بابا؟ (Sepertimu, wahai Ayah?)

Pelanggaran maksim relevansi tersebut dibuktikan dengan adanya tuturan di atas yang dituturkan oleh anak perempuan kepada ayahnya. Ayahnya mengatakan bahwa Tuhan itu Agung sekali, kuat sekali, dan berkuasa atas segala sesuatu. Anak perempuan tersebut menyamakan ayahnya dengan Tuhan, sehingga tuturan ini menyimpang dari maksim kecocokan.

d. Penyimpangan Maksim Pelaksanaan

فوق (Di atas)

Tuturan tersebut menyimpang dari maksim pelaksanaan. Dilihat dari percakapan di dalam cerita tersebut, anak perempuan bertanya kepada ayahnya kemana nanti setelah meninggal, lalu ayahnya menjawab "di atas." Menurut peneliti, tuturan ini kabur dan tidak jelas, sehingga dengan bukti yang jelas tuturan tersebut menyimpang dari maksim pelaksanaan.

\section{Penyimpangan Prinsip Kesantunan dalam Cerita Pendek Jannah al-Athfal Karya Naguib Mahfouz}

a. Penyimpangan Maksim Kebijaksanaan

- لكن لولو جارنا يضربني، و لا يفعل شيئاً جميلاً (Tetapi Lulu, tetangga kita, ia pernah memukulku dan tak pernah berbut baik)

Tuturan anak perempuan tersebut sebagai anak kecil yang polos dan lugu terasa tidak wajar karena secara terus terang berusaha memaksimalkan kerugian orang lain.

- ولكنه سيموت (Tetapi Dia akan mati)

Tuturan di atas juga menyimpang dari maksim kebijaksanaan, yaitu ingin memaksimalkan kerugian terhadap orang lain.

b. Penyimpangan Maksim Kemurahan

- من أحسن ؟ (Siapa yang lebih baik?)

Tuturan tersebut dituturkan oleh anak perempuan tersebut dan ingin memaksimalkan keuntungan dirinya sendiri.

- ضروري و احدة أحسن (Tentunya ada salah satu yang lebih baik) 
Tuturan anak perempuan ini juga bertujuan untuk mendapatkan keuntungan yang maksimal bagi dirinya sendiri.

- أريد أن أبقى دائما مع نادية (Saya ingin selalu bersama Nadia!)

Menurut peneliti, tuturan di atas juga menginginkan keuntungan yang lebih banyak .

- هل أقول لها إنها موضة قديمة و إني موضة جديدة (Apakah dapat saya katakan kepada Nadia bahwa ia mode lama dan saya mode baru?)

Tuturan yang dituturkan oleh anak perempuan tersebut menginginkan untuk mendapatkan keuntungan yang maksimal. Tuturan tersebut dituturkan dengan polos oleh anak perempuan tersebut.

c. Penyimpangan Maksim Penerimaan

Peneliti tidak menemukan penyimpangan dalam maksim ini.

d. Penyimpangan Kerendahan hati

Peneliti tidak menemukan penyimpangan dalam maksim ini.

e. Penyimpangan Kecocokan

- ير ممكن (Tidak mungkin)

Tuturan di atas adalah bentuk ketidaksetujuan ayahnya sebagai lawan tutur kepada penutur bahwa manusia dapat melihat Tuhan secara langsung. Dengan bukti ini juga, peneliti melihat bahwa tuturan ini telah menyimpang dari maksim kecocokan.

- غير ممكن أيضا (Tidak mungkin juga)

Tuturan di atas dituturkan oleh ayahnya sebagai penolakan kepada si anak perempuan itu yang sangat ingin melihat Tuhannya, bahkan melalui televisi.

- ولكنه حي لا يموت (Tetapi Dia tidak akan mati)

Prinsip kesantunan yang dilanggar di dalam tuturan di atas yang tampak pada argumen ayah dari anak perempuan itu yang tidak bersesuaian dengan anak perempuannya yang mengatakan bahawa Tuhan akan mati.

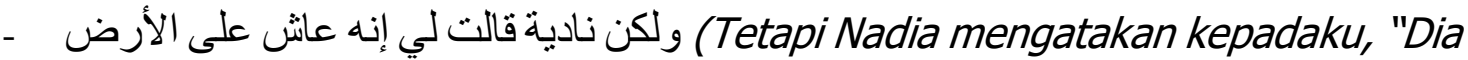
tinggal di bumi")

Penyimpangan prinsip kesantunan yang dilanggar oleh anak perempuan tersebut adalah ketidaksetujuannya terhadap tuturan ayahnya 
bahwa Tuhan tinggal di langit. Sikap penutur tersebut memberikan bukti penolakan terhadap argumen yang diberikan ayahnya tentang Tuhan temannya.

- ولكنك قلت إنه غير حلو (Tetapi tadi Ayah bilang itu tidak menyenangkan)

Dalam maksim kecocokan seharusnya penutur dalam tuturannya mengurangi ketidaksesuaian diri dengan orang lain dan menambah kesesuaian diri dengan orang lain dalam sebuah komunikasi. Tuturan di atas mengindikasikan pertentangan karena pada tuturan sebelumnya ayahnya mengatakan bahwa mati itu tidak menyenangkan. Menurut hemat peneliti, tuturan tersebut telah menyimpang dari maksim kecocokan.

- لكننا لم نفعل أنثياء جميلة بعد (Tetapi sekarang kita belum melakukan hal- hal yang baik)

Tuturan di atas juga mengidentifikasi ketidaksesuaian argumen anak perempuan tersebut yang menuturkan bahwa mereka harus segera mati untuk kembali kepada Tuhan.

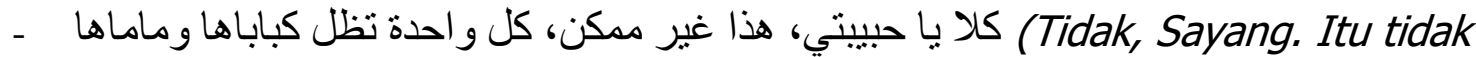
bisa. Tiap orang harus tetap seperti bapak dan ibunya)

Pelanggaran maksim kecocokan dalam tuturan tersebut dapat dibuktikan dengan adanya ketidaksetujuan ayahnya terhadap argumen anak perempuannya yang menginginkan untuk berganti agama menjadi Kristen agar selalu bersama-sama Nadia, temannya.

- كلا يا عزيزتي (Tidak, sayangku)

Tuturan di atas juga mengindikasikan bentuk ketidaksetujuan ayahnya kepada argumen anak perempuannya yang menuturkan bahwa kematian itu menyenangkan.

f. Penyimpangan Kesimpatian

Peneliti tidak menemukan penyimpangan dalam maksim ini.

\section{KESIMPULAN DAN SARAN}

Berdasarkan hasil penelitian dan analisis data yang telah peneliti uraikan dalam pembahasan mengenai pelanggaran prinsip kerja sama dan pelanggaran prinsip kesantunan tuturan dalam cerita pendek Jannah al-Athfâl karya Naguib Mahfouz, maka dapat ditarik simpulan sebagai berikut:

1. Data yang ditemukan peneliti adalah bahwa tuturan-tuturan yang ada dalam cerita pendek Jannah al-Athfâ/karya Naguib Mahfouz menyimpang dari maksim-maksim prinsip kerja sama dan prinsip kesantunan berjumlah 24 tuturan. Secara rinci, 
datanya adalah sebagai berikut; 10 tuturan termasuk dalam pelanggaran prinsip kerja sama dan 14 tuturan termasuk dalam pelanggaran prinsip kesantunan

2. Maksim prinsip kesantunan yang paling banyak dilanggar oleh penutur dan lawan tutur dalam cerita pendek Jannah al-Athfâlkarya Naguib Mahfouz, adalah maksim kecocokan.

3. Maksim kerja sama yang paling banyak dilanggar adalah maksim relevansi dan maksim pelaksanaan. yaitu :

Berdasarkan hasil penelitian, peneliti mengemukakan beberapa saran berikut,

1. Bagi peneliti cerita pendek dan novel yang ingin menciptakan tuturan lawak atau humor, penyimpangan prinsip kerja sama dan penyimpangan kesantunan dapat menjadi alat bantu untuk menciptakan humor yang mengundang senyum dan tawa pembaca.

2. Bagi guru dan siswa, penelitian ini dapat menambah pengetahuan tentang pengajaran pragmatik, khususnya prinsip kerja sama dan prinsip kesantunan beserta penyimpangan prinsip kerja sama dan prinsip kesantunan dalam pembelajaran karya sastra.

\section{REFERENSI}

Djajasudarma, Fatimah. 2010. Metode Linguistik: Ancangan Metode Penelitian dan Kajian. Cetakan Ketiga. Bandung: PT Refika Aditama.

Leech, Geoffry N. 1983. Principles of Pragmatice. London: Longman.

Levinson, Stephen C. 1983. Pragmatics. Cambridge: Cambridge University Press.

Mahsun, M.S. 2006. Metode Penelitian Bahasa: Tahapan Strategi, Metode, dan Tekniknya. Jakarta: PT. Raja Grafindo Persada.

Rahardi, Kuntjana. 2005. Kesantunan Imperatif Bahasa Indonesia. Jakarta: Penerbit Erlangga.

Setyowati, Eka. 2014. "Analisis Penyimpangan Prinsip Kerjasama dan Prinsip Kesopanan dalam Acara Dagelan Curanmor Di Yes Radio Cilacap." ADITYA: Pendidikan Bahasa dan Sastra Jawa 4, No. 3.

Soeparno. 2002. Dasar- dasar Linguistik Umum. Yogyakarta: Tiara Wacana. 